KS. KAZIMIERZ DULLAK

Wydział Teologiczny

Uniwersytetu Szczecińskiego

ORCID: 0000-0002-9202-0433

\title{
ŚMIERĆ ELEMENTEM SPRAWCZYM ROZWIĄZANIA WĘZŁA MAŁŻEŃSKIEGO
}

Treść: Wstęp. - 1. Śmierć w ujęciu medycznym. - 2. Śmierć jako zdarzenie prawne (aspekt prawa cywilnego). - 3. Pojęcie małżeństwa w aspekcie jego nierozerwalności. - 4. Rozwiązanie małżeństwa w świetle prawa Rzeczpospolitej Polskiej (zarys). - 5. Ustanie małżeństwa w świetle przepisów prawa kościelnego. - Zakończenie

\section{Wstęp}

Zjawiskiem nieuchronnym jest towarzysząca człowiekowi śmierć. Mamy z nią do czynienia nie tylko w sytuacjach naturalnych wynikających z procesu starzenia się człowieka albo jako wynik chorób którym nie można na danym etapie zaradzić. Śmierć również intensyfikuje się w skutek zdarzeń losowych lub działań zaprojektowanych przez ludzi. Śmierć w aspekcie prawnym pociąga za sobą wiele skutków prawnych, m.in. zmarły traci zdolność prawną, wygasa ochrona dóbr osobistych zmarłego, ustaje małżeństwo, należy wystawić kartę zgonu następnie pojawia się prawo pochowania ciała zmarłego, otwarcie spadku i prawa dziedziczenia.

Celem niniejszego przedłożenia jest wskazanie skutków wynikających ze śmierci osoby, która uprzednio zawarła związek małżeński. Co powoduje śmierć dla samego małżeństwa jak i współmałżonka zarówno w porządku prawa cywilnego jak i kościelnego? Wcześniej 
jednak trzeba będzie dookreślić czym jest samo zjawisko śmierci zarówno z punktu widzenia medycyny jak i prawa.

\section{1. Śmierć w ujęciu medycznym}

Według potocznego rozumienia śmierć można stwierdzić wówczas, gdy osoba znajduje się w pozycji nieruchomej, a jednocześnie ustają u niej podstawowe funkcje życiowe. Dodatkowo zewnętrznymi elementami wskazującymi na zgon człowieka to: bladość czy zesztywnienie kończyn.

Z perspektywy medycyny, potoczne pojęcie śmierci człowieka, chociaż poprawne, nie jest możliwe do przyjęcia. Człowiek jest istotą bezcenną, aby o jego życiu czy śmierci mogły decydować tak ogólne przesłanki. Dlatego lekarze wraz z rozwojem medycyny (szczególnie anestezjologii i transplantologii) postulowali wypracowanie nowej i bardziej precyzyjnej definicji śmierci, która obejmowałaby swym zakresem wyniki badań nt. mózgu' ${ }^{1}$.

Medycyna sądowa rozróżnia dwa procesy: umierania i śmierci. „Zespół zaburzeń ogólnoustrojowych prowadzących do zaniku czynności biologicznych i biochemicznych koniecznych do utrzymania życia to proces umierania" ${ }^{2}$, natomiast przez śmierć rozumie się „trwałe, nieodwracalne ustanie czynności życiowych organizmu (...). O śmierci decyduje przede wszystkim zatrzymanie czynności najważniejszych dla życia układów: ośrodkowego układu nerwowego, krążenia i oddychania"3. Rozróżnienie to pozwoliło dokonać doprecyzowania rozumienia zagadnienia śmierci i wypracowania trzech szczegółowych pojęć śmierci: pozornej, klinicznej i biologicznej.

Śmierć pozorna określana jest jako „taki stan, w którym czynności układów krążenia i oddychania wprawdzie nie ustają, ale przebiegają

\footnotetext{
${ }^{1}$ Więcej nt postulatu wypracowania szczegółowej definicji śmierci w medycynie: K. SoвCZAK, A. JanASZczy K, Kontrowersje wokół neurologicznego kryterium śmierci mózgu, Forum Medycyny Rodzinnej 6(2012) nr 4, s. 183-185.

${ }^{2}$ Cz. ŻaBA, Wybrane zagadnienia z medycyny sądowej, Poznań 2014, s. 36.

${ }^{3}$ S. Raszeja, W. NasiŁowski, J. Markiewicz, Medycyna sądowa. Podręcznik dla studentów, Warszawa 1990, s. 42.
} 
na bardzo niskim poziomie - zaledwie wystarczającym do zachowania życia (...)" ${ }^{4}$. Do jej zdiagnozowania wystarczą badanie bioelektrycznych czynności serca (EKG) i mózgu (EEG). Istnieje zatem duża możliwość przeżycia o ile parametry życiowe ulegną samoistnemu poprawieniu lub dokona się to poprzez proces reanimacji.

Przez śmierć kliniczną rozumie się ustanie czynności krążeniowo-oddechowych organizmu, czemu towarzyszą symptomaty: zmniejszone napięcie tkanek - zwłaszcza mięśni, bierne ułożenie ciała, brak świadomości i odruchów, brak ruchów oddechowych, brak tętna i tonów serca, bladość powłok oraz ochłodzenie ciała. Żaden jednak z tych objawów sam przez się, ani też wszystkie razem wzięte nie upoważniają do stwierdzenia śmierci w sposób pewny.

Natomiast śmierć biologiczną definiuje się jako nieodwracalną zmianę w narządach ważnych dla życia, a zwłaszcza w tkance mózgowej. Aby móc ją zdiagnozować należy ustalić łącznie następujące kryteria: całkowita utrata świadomości oraz czynności czuciowych i ruchowych, zupełny zanik odruchów i całkowita atonia mięśni, zatrzymanie oddechu, załamanie się ciśnienia tętniczego z chwilą zaprzestania sztucznego podtrzymywania, zapis elektroencefalograficzny - całkowicie linearny, tkanka mózgowa nie pobiera już tlenu oraz ustanie przepływu krwi przez mózg. Z przytoczonych przejawów śmierci można wyprowadzić jeszcze inny podział rodzajów śmierci: mózgowa zdarza się wówczas, gdy ulegną porażeniu lub zniszczeniu ośrodki: oddechowy i krążenia; płucna występuje, gdy zaburzenia w czynności płuc doprowadzają do niedotlenienia krwi i nagromadzenia się w niej nadmiaru dwutlenku węgla; sercowa powodowana uszkodzeniem mięśnia sercowego lub układu przewodzącego wewnętrznego ${ }^{5}$.

Aktualnie w Polsce obowiązuje krążeniowo-oddechowa definicja zgonu człowieka. Śmierć człowieka może stwierdzić jedynie lekarz ${ }^{6}$.

${ }^{4}$ T. Marcinkowski, Medycyna sądowa dla prawników, Szczytno 2010, s. 130.

${ }^{5}$ Tamże, s. 129-133.

${ }^{6}$ „Art. 43. 1. Lekarz może stwierdzić zgon na podstawie osobiście wykonanych badań i ustaleń, z zastrzeżeniem sytuacji określonych w odrębnych przepisach” 
Dokonując badania lekarz zwraca uwagę na symptomy świadczące o ustaniu funkcji oddechowej i krążeniowej organizmu oraz zwraca uwagę na tzw. zewnętrzny wygląd ciała (m.in. występowanie zesztywnienia, plam opadowych czy sztywność źrenic).

Diagnoza śmierci człowieka, w oparciu o obumarcie mózgu, obostrzona jest koniecznością przeprowadzenia ściśle określonych procedur ${ }^{7}$. Może być ona stwierdzona, gdy spełnione są trzy warunki: ustalono przyczynę śpiączki i jest ona wystarczająca dla spowodowania utraty funkcji mózgowych; wykluczona jest możliwość odzyskania jakichkolwiek funkcji mózgowych; ustanie wszystkich funkcji mózgowych trwale utrzymuje się we właściwym czasie obserwacji”". Załącznik do dokumentu Ministra Zdrowia o śmierci mózgowej podaje szczegółową procedurę, którą należy zachować w procesie diagnozy śmierci mózgu' .

\section{2. Śmierć jako zdarzenie prawne (aspekt prawa cywilnego)}

W prawie państwowym pojęcie śmierci człowieka rozumiane jest jako zdarzenie prawne wywołujące istotne skutki na forum cywilnym, do których należy m.in.: utrata zdolności do czynności prawnych, a także - z interesującego nas punktu widzenia - możliwość zawarcia

(Ustawa z dnia 5 grudnia 1996 r. o zawodach lekarza i lekarza dentysty, Dz. U. 1997 nr 28, poz. 152).

${ }^{7}$ Dokonuje tego konsylium lekarzy złożone z trzech specjalistów: lekarza sądowego, intensywnej terapii i neurologa. Zob. E. CravetT (red.), Wielka Encyklopedia Medyczna, t. 21, Warszawa 2011, s. 39.

${ }^{8}$ W. Kania, Kryterium śmierci mózgowej w perspektywie historycznej, Śląskie Studia Historyczno-Teologiczne 40(2007), z. 2, s. 360.

${ }^{9}$ Do najważniejszych objawów śmierci mózgu zalicza się: trwałą śpiączkę, brak odruchów pionowych i permanentny bezdech. Wskazane zostały także badania, które należy wykonać podczas czynności diagnostycznych: reakcja na światło, odruch rogówkowy, próba kaloryczna, reakcje bólowe, odruchy wymiotne i kaszlowe, odruchy oczno-mózgowe i bezdech. Dopiero po spełnieniu powyższych procedur można uznać człowieka na martwego. Zob. Załącznik do Obwieszczenia Ministra Zdrowia z dnia 17 lipca 2007 r.w sprawie kryteriów i sposobu stwierdzenia trwałego nieodwracalnego ustania czynności mózgu (M.P. $2007 \mathrm{nr} 46$ poz. 547). 
nowego związku małżeńskiego przez żyjącego współmałżonka ${ }^{10}$. Brak ustawowej definicji zgonu człowieka, wynika z oczywistego faktu, że w tym zakresie organy wymiaru sprawiedliwości polegają na medycznych procedurach diagnozowania zgonu, wypracowanych przez medycynę sądową.

Polskie prawodawstwo przewiduje trzy drogi postępowania związane ze śmiercią osoby fizycznej:

1. obiektywne stwierdzenie zgonu człowieka poprzez sporządzenie aktu zgonu w USC, na podstawie karty zgonu wystawionej przez lekarza $^{11}$;

2. postępowanie o uznanie za zmarłego;

3. postępowanie o stwierdzenie zgonu.

Pierwszy z wymienionych postępowań nie wymaga wyjaśnień. Drugiego postępowania podmiotem są osoby, które zaginęły a ich nieobecności towarzyszy niepewność co do tego, czy żyją (nieznane jest ich miejsce przebywania) czy już zmarli (nie znaleziono zwłok).

Przyczyny zaginięcia osoby mogą być dwojakie: zwykłe (np. osoba wyszła z domu i nie wróciła lub zaginęła w niewyjaśnionych okolicznościach); nadzwyczajne (np. zagniecie osoby w wyniku katastrofy w ruchu powietrznym bądź morskim).

Przedmiotem postępowania jest uznanie za prawdziwą domniemaną hipotezę, że długotrwała nieobecność osoby może być spowodowana zgonem. Pomimo braku obiektywnych przesłanek przemawiających za śmiercią danej osoby sąd kierując się dużym stopniem prawdopodobieństwa potwierdza śmierć jako zakładane jednocześnie przyczynę i skutek zaginięcia.

Aby sąd, w trybie nieprocesowym, mógł rozpatrzyć przedmiotową sprawę, muszą być spełnione dwa warunki: trwała nieobecność danej osoby i brak jakiegokolwiek kontaktu $\mathrm{z}$ nią oraz niewiadome miejsce jej przebywania; następnie udokumentowana czasowa nieobecność

\footnotetext{
${ }^{10}$ Por. S. Dmowski, S. Rudnicki, Komentarz do Kodeksu Cywilnego. Księga pierwsza - część ogólna, Warszawa 2011, s. 140.

${ }^{11}$ Zob. Art. 92-93 ustawy z dnia 28 listopada 2014 r. Prawo o aktach stanu cywilnego (Dz. U. 2014, poz. 1741, z późn. zm.).
} 
osoby zaginionej. Dla spraw zwykłych - w myśl art. $29 \mathrm{KC}-$ ta nieobecność wynosi:

- 5 lat wobec osób które $\mathrm{w}$ dniu zaginięcia miały minimum 65 lat;

- 10 lat względem osób, które w dniu zaginięcia były pełnoletnie a nie przekroczyły 65 lat;

- $\quad$ w przypadku zaginięcia osoby niepełnoletniej temporalny warunek nie jest brany pod uwagę aż do końca roku kalendarzowego, w którym zaginiony ukończyłby 23 lata; dopiero wtedy rozpoczyna się odmierzanie wymaganego dziesięcioletniego okresu zaginięcia, wymaganego prawem do ogłoszenia postanowienia.

W przypadku nadzwyczajnym art. $30 \mathrm{KC}$ przewiduje następujące czasookresy:

- 6 miesięcy od dnia katastrofy lub innego szczególnego wydarzenia (bez względu na wiek osoby zaginionej);

- 6 miesięcy po upływie 1 roku od planowanego terminu przybycia statku powietrznego lub okrętu morskiego do portu przeznaczenia (w przypadku połączeń rejsowych i gdy nie ustalono miejsca przebywania zaginionej jednostki pasażerskiej);

- 6 miesięcy po upływie 2 lat od dnia posiadania ostatniej informacji nt. zagonionej jednostki (w przypadku rejsów prywatnych bez zgłoszonego portu docelowego);

- 1 rok od dnia ustania bezpośredniego niebezpieczeństwa, w którym istnieje uzasadniona pewność o uczestnictwie w niej zaginionej osoby (w sytuacjach nieprzewidzianych w niniejszym paragrafie np. powódź lub lawina śnieżna).

Postępowanie kończy się wydaniem przez sąd prawomocnego i konstytutywnego postanowienia określającego domniemaną datę śmierci człowieka ${ }^{12}$. Prawne skutki uznania osoby za zmarłą są takie same jak w przypadku faktycznego zgonu osoby.

\footnotetext{
${ }^{12}$ „W postanowieniu stwierdzającym zgon, sąd ma obowiązek ścisłego oznaczenia chwili śmierci, stosownie do wyników postępowania. Jeśli precyzyjne ustalenie tej chwili nie było możliwe, w postanowieniu należy wskazać chwilę najbardziej
} 
Na mocy art. 31 KC prawo wyjątkowo działa wstecz, tzn. że skutki prawne nie następują od momentu wydania wyroku, lecz od czasu wystąpienia zdarzeń, które w opinii sądu uznane zostały za domniemany moment śmierci (w sytuacjach normalnych - od dnia zaginięcia, zaś w sytuacjach nadzwyczajnych - od dnia katastrofy $)^{13}$.

W postępowaniu o stwierdzenie zgonu mamy do czynienia, $\mathrm{w}$ przeciwieństwie do wcześniej omówionego, z prawnym potwierdzeniem wysoce prawdopodobnego faktu śmierci danej osoby.

Podmiotem postępowania są osoby, co do których istnieje przekonanie, że ich śmierć jest niewątpliwa, pomimo braku jednoznacznych dowodów potwierdzających ich zgon. Przedmiotem zaś sprawy jest wola prawnego uregulowania statusu tejże osoby, poprzez wystawienie aktu zgonu.

Zgodnie $\mathrm{z}$ art. $535 \mathrm{KPC}$ aby wszcząć postępowanie muszą być spełnione dwa warunki:

- pewność śmierci osoby poparta bezpośrednimi dowodami (np. protokół z oględzin miejsca katastrofy i zaznania naocznych świadków), jak i w świetle „domniemań faktycznych, gdy okoliczności konkretnego wypadku, przy uwzględnieniu zasad doświadczenia życiowego, wskazują, iż śmierć rzeczywiście nastąpiła"14;

- niesporządzenie dotychczas aktu zgonu z powodu nie odnalezienia ciała denata.

Konsekwencje wydanego w formie nieprocesowej postanowienia są takie same jak w przypadku postępowania o uznanie osoby za zmarłą. Zgodnie z art. $31 \mathrm{KC}$ wywołują skutki prawne od momentu wskazanego w akcie prawnym jako domniemany moment śmierci.

prawdopodobną, o czym mówi art. 538 KPC (...) precyzyjne oznaczenie chwili śmierci powinno polegać na określeniu daty i godziny śmierci. Jeżeli i określenie godziny śmierci jest niemożliwe, za chwilę śmierci uważać się będzie koniec dnia, stanowiącego datę śmierci (w drodze analogii a art. $31 \$ 3 \mathrm{KC}$ )" (K. MıкоŁAJCzu , Uznanie za zmarłego a możliwość zawarcia nowego małżeństwa. Wybrane zagadnienia z prawa cywilnego i kościelnego, Roczniki Nauk Prawnych 23(2013), nr 2, s. 98).

${ }^{13}$ Por. Z. Radwański, Prawo cywilne - część ogólna, Warszawa 1993, s. 130.

${ }^{14}$ S. Dmowski, S. Rudnicki, dz. cyt. s. 141. 


\section{Pojęcie małżeństwa $w$ aspekcie jego nierozerwalności}

Każdy związek małżeński, zawarty z zachowaniem przepisów prawa, jest ważny, lecz swoją pełnię uzyskuje w momencie dopełnienia. Współżycie seksualne małżonków pełni bowiem podwójną funkcję: jednoczącą i prokreacyjną. Prawdę tę ukazał papież Paweł VI w encyklice Humanae vitae: „Albowiem stosunek małżeński z najgłębszej swojej istoty, łącząc najściślejszą więzią męża i żonę, jednocześnie czyni ich zdolnymi do zrodzenia nowego życia, zgodnie z prawami zawartymi w samej naturze mężczyzny i kobiety" (nr 12).

Kwestię dopełnienia małżeństwa precyzuje zapis kan. $1061 \$ 1 \mathrm{KPK}$ wg którego czynność ta dokonuje się w akcie małżeńskim, czyli fizycznym zespoleniu małżonków o charakterze seksualnym. Przez akt seksualny rozumie się cielesne złączenie małżonków, które dokonuje się na drodze połączenia męskich i żeńskich narządów płciowych. Aby móc określić akt seksualny jako właściwy winny dokonać się trzy części składowe: wzwód, penetracja i ejakulacja oraz potencjalna inseminacja. Gdy brakuje jednego z trzech pierwszych elementów, czy to z przyczyn natury medycznej, psychicznej albo z świadomego działania, akt seksualny nie może spełnić przewidzianej sobie funkcji. Wynika z tego jednoznacznie, że moralnie złym są wszelkie praktyki seksualne będące wynaturzeniem tego aktu, a także stosowanie jakichkolwiek środków antykoncepcyjnych oraz leków czasowo obezpładniających ${ }^{15}$. Należy również dodać, iż współżycie płciowe wymuszone, bez liczenia się ze stanem oraz z uzasadnionymi życzeniami współmałżonka, nie jest prawdziwym aktem miłości i dlatego sprzeciwia się temu, czego słusznie domaga się ład moralny we wzajemnej więzi między małżonkami (HV 13). Z perspektywy kan. 125 $\$ 1 \mathrm{KPK}$ należy takie małżeństwo uznać za niedopełnione. Innymi słowy, o dopełnieniu małżeństwa można mówić jedynie wówczas, gdy

\footnotetext{
${ }^{15}$ Zob. PAWE⿺ VI, Encyklika o zasadach moralnych $w$ dziedzinie przekazywania życia ludzkiego „Humanae vitae”, Rzym 1968, nr 14 i 16; JAN PAWE€ II, Adhortacja apostolska o zadaniach rodziny chrześcijańskiej w świecie współczesnym „Familiaris consortio”, Rzym 1981, nr 32; JAN PAWEŁ II, Encyklika o wartości i nienaruszalności życia ludzkiego „Evangelium vitae”, Rzym 1995, nr 13.
} 
prawidłowo dokonany akt seksualny uwzględnia wzajemną wolność partnerów i otwartość na możliwość przyjęcia nowego życia. Nierozerwalność zatem oznacza tę właściwość ważnie zawartego i dopełnionego małżeństwa, która sprawia, że wypływający z niego węzeł może być rozwiązany tylko przez śmierć jednego z małżonków (kan. 1141 KPK). Trwałość jest konsekwencją prawa natury oraz prawa Bożego pozytywnego (Łk 16,18; 1Kor 7, 10-11; Ef 5, 22-23) ${ }^{16}$. Wobec powyższego, tak ukształtowane małżeństwo jest nierozerwalne wewnętrznie i zewnętrznie, czyli nie może być rozerwane własną powagą kontrahentów, a także przez tych którzy dzierżą władzę w społeczności.

\section{Rozwiązanie małżeństwa $\mathrm{w}$ świetle prawa Rzeczypospolitej Polskiej (zarys)}

Obowiązujące w Polsce prawo małżeńskie, wyrażone w Kodeksie rodzinnym i opiekuńczym, uznaje cztery przyczynki powodujące ustanie ważnego małżeństwa z mocy prawa: rozwód, unieważnienie małżeństwa, biologiczna śmierć współmałżonka oraz sądowe uznanie współmałżonka za zmarłego. Dla potrzeb niniejszego opracowania uwaga zostanie skoncentrowana na dwóch ostatnich przypadkach, z pominięciem pierwszych.

Małżeńska przysięga, wypowiadana w momencie zaślubin, w świetle KRO stanowi akt prawny tworzący trwałą i dozgonną wspólnotę małżeńską pomiędzy kobietą i mężczyzną. Wobec tego śmierć jednej ze stron w sposób naturalny pociąga za sobą ustanie związku małżeńskiego: „W razie uznania jednego z małżonków za zmarłego domniemywa się, że małżeństwo ustało z chwilą, która w orzeczeniu o uznaniu tego małżonka za zmarłego została oznaczona jako chwila jego śmierci” (art. $55 \$ 1$ ).

${ }^{16}$ T. PAwluk, Przesłanki nierozerwalności małżeństwa, Prawo Kanoniczne 26(1983), nr 1-2, s. 223-238; J. KR AJCZYŃsKi, Nierozerwalność małżeństwa w doktrynie i ustawodawstwie Kościoła, Ius Matrimoniale 9(2004), 48-85; B. Ferdek, Nauczanie Kościoła katolickiego nierozerwalności małżeństwa w aspekcie dogmatyczno-historycznym, Sympozjum 19(2010) nr 1, s. 33-36. 
Potwierdzeniem tego wydarzenia w świetle prawa jest wydany przez USC akt zgonu, sporządzony na podstawie karty zgonu sporządzonej przez lekarza, który po przeprowadzonym badaniu ciała osoby, orzekł jej śmierć.

Inną figurą prawną jest sądowe uznanie współmałżonka za zmarłego. Kwestię niniejszą w sposób jasny i precyzyjny rozstrzyga przytoczony wyżej art. $55 \$ 1 \mathrm{KRO}$, który stwierdza wyraźnie, że ogłoszone przez sąd konstytutywne postanowienie o uznaniu za zmarłego osoby, powoduje ustanie małżeństwa, przez rozwiązanie prawnego węzła wraz z domniemaną datą jego śmierci, ogłoszoną w powyższym dokumencie.

Dla żyjącego współmałżonka osoby, co do której orzeczono domniemaną śmierć, rodzi to skutki prawne, podobne jak w przypadku naturalnego zgonu partnera. Chodzi o to, że żyjącemu współmałżonkowi nadaje się stan wdowy/wdowca umożliwiającego wstąpienie w kolejny związek małżeński.

Jako że uznanie za zmarłego jest jedynie potwierdzeniem wysoce prawdopodobnej hipotezy o przypuszczalnej śmierci zaginionej osoby, towarzyszy temu nikła możliwość odnalezienia się wspomnianej osoby, która by żyła. Pojawia się więc naturalne pytanie o status jego małżeństwa - czy jego małżeństwo nadal istnieje?

W przypadku, gdy owdowiały małżonek wstąpi w nowy związek małżeński - zgodnie z dyspozycją art. $55 \$ 2 \mathrm{KRO}^{17}$ - jego poprzednie małżeństwo, $z$ odnalezionym partnerem, zostało definitywnie rozwiązane $z$ chwilą zawarcia nowego małżeństwa ${ }^{18}$.

\footnotetext{
${ }^{17}$ Art. $55 \$ 2$ KRO: „Jeżeli po uznaniu jednego z małżonków za zmarłego drugi małżonek zawarł nowy związek małżeński, związek ten nie może być unieważniony z tego powodu, że małżonek uznany za zmarłego żyje albo że jego śmierć nastąpiła w innej chwili aniżeli chwila oznaczona w orzeczeniu o uznaniu za zmarłego. Przepisu tego nie stosuje się, jeżeli w chwili zawarcia nowego związku małżeńskiego strony wiedziały, że małżonek uznany za zmarłego pozostaje przy życiu”.

18 „W nawiązaniu do treści art. $31 \mathrm{KC}$, art. $55 \$ 1 \mathrm{KRO}$ postanawia, iż w razie uznania jednego z małżonków za zmarłego domniemywa się, że małżeństwo ustało z chwilą, która w orzeczeniu sądowym została oznaczona jako chwila jego śmierci. Skutek domniemania z art. $55 \$ 1$ wyraża się w zniesieniu względem małżonka,
} 
Sprawa jest trudniejsza w przypadku, gdy owdowiały małżonek pozostaje w stanie wolnym. Na samym początku należy przypomnieć, że sądowe postanowienie w trybie nieprocesowym ma charakter prawomocny, gdyż „ma powagę rzeczy osądzonej” (art. 366 KPC). Jako takie wywiera skutki prawne, które mogą być zaskarżone w apelacji (art. $518 \mathrm{KPC}^{19}$ ), głównie w przypadku pojawienia się nowych dowodów kwestionujących prawdziwość domniemania śmierci. Prawo cywilne nie przewiduje natomiast kategorii automatycznego uchylenia prawomocności postanowienia sądowego. Tak więc istnieje możliwość dochodzenia unieważnienia postanowienia sądu na drodze postępowania o uchylenie prawomocnego wyroku. Postępowanie w tej sprawie opisane jest w art. 539-543 KPC.

Bardzo ważne jest w tej kwestii podkreślenie, że osoba, co do której stwierdzono domniemaną śmierć, nie ma osobowości prawnej (brak aktu urodzenia, numeru pesel czy numeru ubezpieczenia zdrowotnego). Chociaż fizycznie żyje, to w świetle prawa nie istnieje. Uchylenie postanowienia sądowego o domniemaniu śmierci ma zaowocować przywróceniem prawnego stanu faktycznego dla osoby-podmiotu sprawy.

Art. 542-543 KPC w tej sprawie ustanawiają dwie drogi postępowania:

1. jeśli osoba jest samoświadoma, czyli zna swoje podstawowe dane oraz inne ważne fakty ze swojego życia i w postępowaniu sądowym potwierdzi swoją tożsamość, sąd uchyli postanowienie o jego domniemanej śmierci, czym otworzy dalszą procedurę do przywrócenia osobowości prawnej;

który nie został uznany za zmarłego, zakazu przewidzianego $\mathrm{w}$ art. $13 \$ 1$. Z chwilą zawarcia cum bona fide nowego małżeństwa, małżeństwo poprzednie ustaje. Wskutek tego późniejsza wiadomość o tym, że uznany za zmarłego żyje, nie ma wpływu na ważność nowego małżeństwa" (K. Pietrzy Kowski (red.), Kodeks rodzinny i opiekuńczy. Komentarz, Warszawa 2012, s. 536.)

${ }^{19}$ Art. 518 KPC: „Od postanowień sądu pierwszej instancji orzekających co do istoty sprawy przysługuje apelacja. Na inne postanowienia sądu pierwszej instancji, w wypadkach wskazanych w ustawie, przysługuje zażalenie". 
2. w przypadku, gdy osoba nie jest samoświadoma (utraciła pamięć, jest w stanie śpiączki lub wegetatywnym) a odnaleziona została na terenie Rzeczpospolitej, to sprawę o ustanie interesującego postanowienia sądowego może wnieść przedstawiciel służby publicznej (np. policji, prokuratury czy straży granicznej), jak i inna zainteresowana sprawą osoba (np. pracownik schroniska, w którym przebywa ta osoba). Sąd, po przeprowadzeniu dowodu, uchyli wydane wcześniej przez siebie postanowienie. ${ }^{20}$

W obydwu wariantach skutek jest ten sam - uznanie danej osoby za nadal żyjącą. Konsekwencją rzeczonego uchylenia jest wszczęcie procedury administracyjnej, dzięki której wystawią tejże osobie najważniejsze dokumenty potwierdzające jej tożsamość.

Przechodząc do odpowiedzi dotyczącej statusu małżeństwa odnalezionej osoby i jego dawnego współmałżonka należy stwierdzić, że polskie prawo cywilne nie przewiduje konwalidacji małżeństwa ${ }^{21}$ w takim przypadku. Chociaż postanowieniem sądu uchylone zostało domniemanie śmierci osoby, nie oznacza to jednak unieważnienia skutków powstałych w wyniku ogłoszenia wcześniejszego postanowienia. W wyniku tego, małżeństwo tychże osób ustało i nie można cofnąć jego wygaśnięcia. W przypadku gdyby odnaleziony człowiek chciał powrócić do małżeństwa, to za zgodą dawnego współmałżonka, mogą jedynie wystąpić do USC o udzielenie im ślubu, gdyż w świetle prawa są ludźmi stanu wolnego.

\footnotetext{
${ }^{20}$ Przez przeprowadzenie dowodu należy rozumieć postępowanie mające na celu zidentyfikowanie osoby, w przypadku gdy nie istnieją jakiekolwiek domysły co do jej danych personalnych, a gdy takie domysły istnieją, w celu ich zweryfikowania.

${ }^{21}$ Termin konwalidacja dotyczy tych małżeństw, które były zawierane z tytułem do ich nieważności, a więc zostały zawarte mimo zakazu prawa. Konwalidacja powoduje uważnienie małżeństwa, jeżeli przeszkoda do jego ważności ustała (np. zawarcie małżeństwa mimo wymaganego wieku, bez zgody sądu czyni małżeństwo nieważnym, lecz po osiągnięciu pełnoletniości, może być konwalidowane (zob. J. Ignatowicz, M. Nazar, Prawo rodzinne, Warszawa 2006, s. 208-209).
} 


\section{Ustanie małżeństwa $\mathrm{w}$ świetle przepisów prawa kościelnego}

Małżeństwo sakramentalne ze swej natury powoduje zawiązanie trwałego, wieczystego, wyłącznego i nierozerwalnego węzła małżeńskiego między wzajemnie oddającymi się sobie i przyjmującymi się małżonkami. Jako takie „małżeństwo zawarte i dopełnione nie może być rozwiązane żadną ludzką władzą i z żadnej przyczyny, oprócz śmierci" (kan. 1141 KPK). Prawodawca kodeksowy podkreśla tutaj, że jedynie wydarzenie jakim jest śmierć współmałżonka, w sposób ważny rozwiązuje prawowiernie zawiązany węzeł małżeński. Zatem stanowczo wykluczona została jakakolwiek władza świecka czy kościelna mogąca dokonać rozwiązania małżeństwa. Nie mogą tego dokonać również sami małżonkowie. Tym samym Kościół negatywnie odnosi się do instytucji rozwodu w słowach: „Rozwód jest poważnym wykroczeniem przeciw prawu naturalnemu. Zmierza do zerwania dobrowolnie zawartej przez małżonków umowy, by żyć razem aż do śmierci. Rozwód znieważa przymierze zbawcze, którego znakiem jest małżeństwo sakramentalne. Fakt zawarcia nowego związku, choćby był uznany przez prawo cywilne, powiększa jeszcze bardziej ciężar rozbicia; stawia bowiem współmałżonka żyjącego w nowym związku w sytuacji publicznego i trwałego cudzołóstwa" (KKK 2384).

Podobnie prawodawstwo kościelne nie dopuszcza kategorii unieważnienia małżeństwa. Istnieje w Kościele następujące rozróżnienie: małżeństwo ważne i dopełnione, ważne i niedopełnione oraz nieważne od samego początku. Nieważność małżeństwa w nauce i prawodawstwie Kościoła oznacza, że już w chwili zawierania związku małżeńskiego u jednego lub obu nupturientów istniała przeszkoda zrywająca, uniemożliwiająca dokonanie tego aktu, a co za tym idzie, sam akt czyniła nieważnym ${ }^{22}$. Za podstawę nieważności możemy także uważać wady zgody małżeńskiej (kan. 1095-1107 KPK), jak również brak lub błędy dotyczące formy zawarcia małżeństwa (kan. 1108-1123 KPK). Jak zaznacza R. Sztychmiler procesy o stwierdzenie nieważności małżeństwa nie godzą w przymioty sakramentalnego małżeństwa, „(...) gdyż w tych sytuacjach w ogóle nie doszło do za-

${ }^{22}$ Por. kan. 1073; zob. też kan. 1083-1094. 
wiązania małżeństwa. Małżeństwo było wprawdzie zawierane, ale nieważnie. Nie powstał więc węzeł małżeński i oficjalnie ogłasza się, że domniemani małżonkowie są faktycznie osobami wolnymi"23.

Śmierć jednego z małżonków może być rzeczywista lub domniemana. Pierwsza wynika ze stwierdzenia przez lekarza ustania czynności życiowych człowieka na podstawie bezpośredniego badania ciała. Natomiast śmierć domniemana jest wynikiem uznania przez organ do tego uprawniony (państwowy lub kościelny) jako wysoce prawdopodobnej przesłanki, w myśl której długotrwała nieobecność człowieka wynika z jego śmierci.

W unormowaniach Kodeksu Jana Pawła II znajduje się dyspozycja prawna dotycząca procedury stwierdzenia domniemanej śmierci współmałżonka - kan. $1707^{24}$ : \$1. Ilekroć śmierć współmałżonka nie może być potwierdzona autentycznym dokumentem kościelnym lub państwowym, drugi małżonek nie jest wolny od węzła małżeńskiego, chyba że biskup diecezjalny wydał deklaracje o jego domniemanej śmierci. \$2. Biskup diecezjalny może wydać deklarację, o której w\$1, tylko wtedy, jeżeli po przeprowadzeniu odpowiednich dochodzeń, z zeznań świadków, z rozgłosu albo z poszlak osiagnie moralny pewność o śmierci współmałżonka. Sama nieobecność współmałżonka, nawet długotrwała, nie wystarcza. \$3. W wypadkach niepewnych i skomplikowanych biskup winien zasięgnąć rady Stolicy Apostolskiej.

Już na wstępnie należy zaznaczyć, że chociaż wspomniane przepisy proceduralne zaliczone zostały do procesów małżeńskich, to

\footnotetext{
${ }^{23}$ R. SzTychmiler, Ochrona trwałości małżeństwa w prawie kanonicznym i polskim oraz w Konkordacie z 28 lipca 1993 roku, Roczniki Nauk Prawnych 5(1995), s. 100 .

${ }^{24}$ Procedury w przedmiotowej sprawie poprzedzające obowiązujący Kodeks zostały zaprezentowane i opatrzone niezbędnymi komentarzami w: publikacjach: M. Greszata-Tulusiewicz, P. Tulusiewicz, Skutki deklaracji domniemanej śmierci w prawie kanonicznym a skutki uznania za zmarłego w polskim prawie rodzinnym. Studium prawno-porównawcze, w: Vir Ecclesiae deditus. Księga dla uczczenia Księdza Profesora Edwarda Góreckiego, red. W. Irek, Wrocław 2011, s. 91-100; R. SzTYCHMILER, Stwierdzenie domniemanej śmierci współmałżonka, Ius Matrimoniale 7(2002), s. 151-166.
} 
jednak charakter postępowania sądowego wskazuje jednak na proces administracyjny ${ }^{25}$.

Deklaracja domniemanej śmierci, na kanwie prawa kościelnego, analogicznie do prawa świeckiego, ma - jak samo nazewnictwo wskazuje - jedynie charakter deklaratywny. Nie stwierdza w sposób wykluczający jakąkolwiek wątpliwość stanu faktycznego, że nieobecność zaginionego współmałżonka jest wynikiem tylko i wyłącznie jego śmierci.

Celem wydania tejże deklaracji jest umożliwienie współmałżonkowi zaginionej osoby wejścia w nowy związek małżeński ${ }^{26}$. Motywem dla złożenia prośby do własnego biskupa diecezjalnego o dokument jest prawidłowo ukształtowana wola zmierzająca do uniknięcia grzechu i publicznego zgorszenia, jakie spowodowałby związek z nowym partnerem. Dokument ten jest potrzebny na etapie kanonicznego badania narzeczonych, $w$ celu upewnienia się duchownego o braku

${ }^{25}$ Por. G. Erlebach, A. Dzięga, J. Krukowski, R. Sztychmiler, Komentarz do Kodeksu Prawa Kanonicznego, t. 5. Księga VII Procesy, Poznań 2007, s. 391. Jak zaznacza R. Sztychmiler postępowanie o domniemaną śmierć może zmienić charakter z postępowania administracyjnego na proces sądowy w trzech przypadkach: „1) jeśli ktoś ze strony zmarłego zaprzecza jego śmierci; 2) jeśli biskup zlecił obrońcy w. m. udział w sprawie z pozycji przeciwnej; 3) jeśli problem ten wyniknie jako sprawa wpadkowa w innym procesie (np. o nieważność małżeństwa). W sytuacjach tych konieczne jest dochodzenie sądowe, jako zwykły proces sporny, proces ustny lub jako sprawa wpadkowa (R. SzTyCHMiLer, Stwierdzenie domniemanej..., s. 159).

${ }^{26}$ „Jako dowodu śmierci, współmałżonka należy żądać przedstawienia autentycznego dokumentu kościelnego lub dokumentu władzy świeckiej stwierdzającego zgon tej osoby. Nie wystarczy natomiast cywilny dokument domniemanej śmierci lecz wymaga się, zgodnie z kan. 1707, przeprowadzenia procesu dotyczącego domniemanej śmierci współmałżonka. Ta różnica w traktowaniu dokumentów wynika stąd, że Kościół opiera swój proces na innych kryteriach. O sądowy kościelny dekret wdowieństwa należy się postarać we wszystkich wypadkach, w których zgonu współmałżonka nie można udowodnić urzędowymi dokumentami kościelnymi lub świeckimi. W takim wypadku oprócz zebrania wszystkich możliwych dokumentów należy uwzględnić formularz XI zawierający pytania dla świadków w sprawie stwierdzenia domniemanej śmierci zaginionego i przedstawić go Kurii diecezjalnej do decyzji" w: Instrukcja Episkopatu Polski o przygotowaniu do zawarcia matżeństwa w kościele katolickim (13 XII 1989), Warszawa 1989, nr 55; zob. kan. $1085 \$ 1$. KPK. 
przeszkód do ważnego zawarcia małżeństwa (kan. 1066 KPK). Istotną przeszkodą w tej mierze jest trwanie węzła małżeńskiego, który pomimo zupełnego, trwałego i długoletniego faktycznego nieistnienia, nadal jest ważny (kan. $1085 \$ 2 \mathrm{KPK}$ ).

Prawo do wniesienie prośby o wydanie wspomnianej deklaracji przysługuje jedynie żyjącemu współmałżonkowi, to oznacza że nie mogą tego uczynić ani wstępni, ani zstępni domniemanego zmarłego $^{27}$.

Warto zwrócić uwagę na motywy, w świetle kan. 1707 \$1 KPK, którymi winien się kierować biskup wydający omawiany dokument:

1. motyw prawny - brak autentycznego dokumentu publicznego o śmierci małżonka sporządzonego przez organy władzy kościelnej lub państwowej (por. kan. 1540: $1541 \mathrm{KPK})^{28}$;

2. motyw pastoralny - jeden ze współmałżonków przypuszczalnie jest pewien śmierci drugiego współmałżonka i chce zawrzeć nowe małżeństwo kanoniczne, by nie pozostawać w związku małżeńskim jedynie cywilnym lub konkubinacie;

3. formalna prośba współmałżonka zamierzającego zawrzeć nowe małżeństwo, skierowana do biskupa diecezji, aby wydał deklarację o domniemanej śmierci współmałżonka ${ }^{29}$.

Prowadzenie etapu rozpatrywania sprawy biskup może zlecić powołanemu zespołowi kapłanów (np. trybunałowi kościelnemu) lub pojedynczemu kapłanowi (np. oficjałowi sądu) ${ }^{30}$. Faza dowodowa może być przeprowadzona również przez właściwego dla sprawy proboszcza parafii. W takim przypadku jest on zobligowany do przeprowadzenia postępowania dowodowego wg następujących wskazań:

\footnotetext{
${ }^{27}$ Por. R. Sztychmiler, Stwierdzenie domniemanej...,s. 156-157.

${ }^{28}$ Dokumentem kościelnym jest świadectwo zgonu wydane przez proboszcza parafii na podstawie parafialnej księgi zgonów, zaś dokumentem państwowym jest świadectwo zgonu wydane przez USC.

${ }^{29}$ G. Erlebach, A. Dzięga, J. Krukowski, R. Sztychmiler, Komentarz..., s. 391.

${ }^{30}$ T. PAwluk, Prawo kanoniczne według Kodeksu Jana Pawła II, t. 4, Olsztyn 1990, s. 347.
} 
1. należy przesłuchać protokolarnie stronę owdowiałą na okoliczność faktu śmierci współmałżonka oraz zgłoszenia świadków $\mathrm{z}$ podaniem stopnia pokrewieństwa;

2. należy przesłuchać protokolarnie świadków;

3. proboszcz winien zgromadzić wszystkie stosowne i możliwe do uzyskania dokumenty, dostarczone głównie przez proszącego (m.in. odpowiedzi instytucji pomagających w odszukaniu zaginionego, wycinki z gazet, listy, itp.);

4. o ile zgromadzone dowody wydają się być przekonujące, należy pomóc osobie owdowiałej napisać prośbę do biskupa dołączając oprócz zgromadzonych dowodów, świadectwo ślubu stron, świadectwa kwalifikacyjne zeznających, relację proboszcza $\mathrm{z}$ dochodzenia oraz jego opinię w sprawie prośby ${ }^{31}$.

Osoby które prowadzą sprawę z upoważnienia biskupa, po dostatecznym zbadaniu sprawy lub po wyczerpaniu różnych możliwości przedstawią sprawę biskupowi z jednoczesną rekomendacją lub jej brakiem $^{32}$. Decyzja biskupa pozostaje wolną od wszelkich sugestii. Do wydania wyroku potrzebna jest biskupowi moralna pewność, którą „osiąga na podstawie dokumentów przesłanych z parafii albo zebranych przez wyznaczonego kapłana lub trybunał"33.

Z punktu jurysdykcji kościelnej niepodważalnym dokumentem śmierci jest metryka zgonu, stanowiąca odpis z parafialnej księgi zmarłych, która - zgodnie z kan. $1540 \$ 1 \mathrm{KPK}$ - sporządzana jest na podstawie państwowego aktu zgonu lub innego zaświadczenia urzędowego, opartego na oględzinach zwłok i ustaleniach nie budzących wątpliwości ${ }^{34}$. Trzeba nadto stwierdzić, że wydane przez sąd świecki orzeczenie o domniemanej śmierci współmałżonka, nie jest wystarczającym dowodem potwierdzającym śmierć danej osoby, na forum kościelnym. Zatem wyrok sądu państwowego nie wywołuje automatycznie tego samego skutku na kanwie kanonicznej.

\footnotetext{
${ }^{31}$ R. Sztychmiler, Stwierdzenie domniemanej..., s. 161-162.

${ }^{32}$ TAMŻE, s. 163.

${ }^{33}$ M. Greszata-Telusiewicz, P. Telusiewicz, Skutki deklaracji..., s. 96.

34 TAMŻE, s. 92.
} 
W celu skutecznego przeprowadzenia rozpoznania sprawy gromadzi się materiał dowodowy do którego przynależą (kan. 1530-1531,1539-1543,1547-1550):

a. przede wszystkim zeznania wiarygodnych świadków:

- bezpośredni uczestnicy wydarzenia (nieszczęśliwego wypadku, katastrofy itp.) będącego domniemaną przyczyną zgonu zainteresowanego

- współmałżonek zaginionego ${ }^{35}$

- członkowie bliskiej rodziny i przyjaciele, znający sprawę ze słyszenia, w celu wykluczenia innych okoliczności, które wyjaśniałyby zaginięcie i permanentną nieobecność osoby ${ }^{36}$;

b. dokumenty sporządzone przez organy państwowe (sąd, prokuratura, policja, organizacje ratownicze (GOPR, WOPR)) w wyniku podjętych przez nich działań poszukiwawczo-wyjaśniających;

c. domniemania wyciągnięte na podstawie zeznań świadków bądź analizy przedłożonych dokumentów.

Wartości dowodowej nie posiada „(...) domniemanie ludzkie (praesumptio hominis) śmierci współmałżonka wynikające $\mathrm{z}$ faktu jego zwyczajnej nieobecności, chociażby przez długi czas. Nie wystarcza również domniemanie prawne (praesumptio iuris), jakie w niektórych państwach ustawy cywilne nakazują przyjąć w razie stwierdzenia nieobecności współmałżonka przez określony czas" ${ }^{{ }^{37}}$.

\footnotetext{
${ }^{35}$ „Poszukując poszlak należy wziąć również pod uwagę moralną stronę zaginionego małżonka, między innymi: czy był osobą religijną, czy był przywiązany do małżonka dzieci rodziny, czy samowolnie opuścił dom, czy pisał listy, czy istniały powody, dla których mógłby świadomie zerwać wspólnotę małżeńską, czy brał udział w działaniach wojennych itp." (K. MıкоєAJCzuк, Uznanie za ..., s. 115).

${ }^{36}$ „Przesłuchując tych świadków należy ustalić: kiedy, od kogo i w jakich okolicznościach dowiedzieli się o śmierci lub innych ważnych zaznawanych faktach. Gdyby ich wiadomości pochodziły z jednego źródła, wartość ich zeznań sprowadzałaby się do jednego świadectwa i zależna byłaby od wiarygodności tego źródła” (R. Sztychmiler, Stwierdzenie domniemanej ..., s. 160).

${ }^{37}$ G. Erlebach, A. Dzięga, J. Krukowski, R. Sztychmiler, Komentarz do ..., s. 391 .
} 
W postępowaniu procesowym, obok biskupa diecezjalnego lub delegowanego przez niego kapłana lub trybunału kościelnego, udział bierze również notariusz, a także powinien być obecny rzecznik sprawiedliwości, chociaż obecność obrońcy węzła małżeńskiego nie jest wymagana $^{38}$.

W powyższym świetle przebieg procesu wygląda następująco:

a. analiza wniosku, dokonana przez biskupa diecezjalnego, o wszczęcie postępowania kościelnego ws. wydania deklaracji o domniemaną śmierć współmałżonka;

b. wydanie postanowienia o wszczęciu lub odmowie wszczęcia postępowania procesowego;

c. wskazanie podmiotu prowadzącego postępowanie wyjaśniające, np. proboszcz strony powodowej lub trybunał kościelny, który gromadzi materiały dowodowe;

d. wydanie edyktu wzywającego osoby mogące mieć wiedzę o śmierci, aby powiadomiły o tym biskupa lub wyraziły sprzeciw wobec zamierzonego małżeństwa ${ }^{39}$;

e. postępowanie dowodowe ${ }^{40}$;

f. opinia rzecznika sprawiedliwości o ile brał udział ${ }^{41}$;

g. przedstawienie wniosków ordynariuszowi prowadzącemu sprawę.

h. wydanie sentencji końcowej.

W trudnych i skomplikowanych przypadkach ordynariusz miejsca, na terenie którego rozpatrywana jest omawiana sprawa - zgodnie z kan. 1707 \$ 3 KPK - powinien zasięgnąć rady Kongregacji ds. Kultu Bożego i Dyscypliny Sakramentów, w celu poinstruowania o dalszym postępowaniu.

\footnotetext{
${ }^{38}$ Por. K. MikoŁajczuk, Uznanie za zmarłego..., s. 113.

${ }^{39}$ P. Majer (red.), Kodeks Prawa Kanonicznego. Komentarz, Kraków 2011, s. 1282.

${ }^{40}$ Zaleca się aby faza dowodowa przeprowadzona została na wzór postępowania sądowego zgodnie z przepisami dotyczącymi procesu spornego (por. R. SzTrch-MILER, Stwierdzenie domniemanej..., s. 159).

${ }^{41}$ P. Majer (red.), Kodeks ..., s. 1282.
} 
Istnieje jeszcze możliwość pośrednia - na co wskazuje Sztychmiler - przekazania sprawy do sądu kościelnego diecezji, której ordynariusz rozpatruje sprawę, celem ponownego jej zbadania. W przypadku wypracowania przez sąd takiej samej konkluzji jak ordynariusz, nabiera on pewności co do słuszności właściwej odpowiedzi na wnioskowaną prośbę. W przypadku dwóch wykluczajacych się konkluzji biskup powinien wówczas zwrócić się z prośbą do wskazanej Kongregacji ${ }^{42}$.

Skoro, jak wcześniej zaznaczono, mamy do czynienia z postępowaniem procesowym, biskup może ogłosić jedną z dwóch możliwych odpowiedzi: pozytywną - deklarującą domniemaną śmierć osoby lub negatywną - nie stwierdzającą jej w sposób dostateczny ${ }^{43}$.

Możemy zatem wywnioskować, że w przypadku braku wystarczających dowodów, nieklarowności sprawy, braku wystarczającej moralnej pewności, biskup wstrzymuje się od wydania pozytywnej odpowiedzi.

Decyzja biskupa wraz z jej uzasadnieniem powinna być wydana $\mathrm{w}$ formie pisemnej, chociaż przepisy prawa procesowego nie odnoszą się wprost do takiej dyspozycji ${ }^{44}$. Ponadto powinna zawierać potwierdzenie istnienia bardzo niskiego prawdopodobieństwa, że w świetle przedstawionych argumentów i dowodów - osoba ta żyje. W przypadku odnalezienia się zaginionej osoby i potwierdzenia jej tożsamości, niniejszy dokument automatycznie traci swoją moc, a wywołane przezeń skutki uważa się za nieważne ${ }^{45}$.

Skutkiem wydania dokumentu o domniemanej śmierci małżonka jest przywrócenie żyjącego partnera do stanu wolnego i umożliwienie

\footnotetext{
${ }^{42}$ Por. R. Sztychmiler, Stwierdzenie domniemanej ..., s. 164.

${ }^{43}$ „Małżonek, który czuje się pokrzywdzony negatywnym orzeczeniem biskupa, ma prawo wnieść rekurs do Kongregacji ds. Kultu Bożego i Dyscypliny Sakramentów. Przed tym odwołaniem wolno małżonkowi zwrócić się ponownie do biskupa z umotywowaną prośbą (by ten poprawił lub odwołał dekret), która poparta jest nowymi dowodami świadczącymi o domniemanej śmierci współmałżonka” (K. MIKOŁAJCZUK, Uznanie za zmarłego ..., s. 116).

${ }^{44}$ R. Sztychmiler, Stwierdzenie domniemanej ..., s. 163.

45 TAMŻE, s. 164-165.
} 
mu zawarcie nowego związku małżeńskiego. Osoba, która uzyskała kanoniczną deklarację domniemanej śmierci współmałżonka, w przypadku jego odnalezienia się, zobowiązana jest do poinformowania o tym fakcie właściwego ordynariusza ${ }^{46}$.

Podobnie jak w przypadku prawa cywilnego, tak i kościelnego nasuwa się szczegółowe pytanie o status małżeństwa między rzeczonymi małżonkami. W przypadku pozostawania żyjącego partnera w stanie wolnym, można jednoznacznie stwierdzić, że ich małżeństwo jest nadal ważne. Sprawa jest bardziej skomplikowana w przypadku zawarcia nowego małżeństwa przez rzekomo owdowiałego małżonka. Z analizy norm kodeksowych wynika więc jasno, że w takim przypadku ważne jest pierwsze małżeństwo, a więc to z osobą odnalezioną, zaś ponowne jej małżeństwo uważa się za nieważne, nawet pomimo zawierania go w dobrej wierze. Na współmałżonku odnalezionej osoby spoczywa obowiązek powrotu do stanu sprzed jego zaginięcia, a więc wzbudzenia wspólnoty małżeńskiej z prawowitym mężem lub prawowitą żoną. W przypadku zaś posiadania przez pozostającego przy życiu współmałżonka potomstwa $\mathrm{z}$ nowego związku - to zgodnie z normą kan. 1137 KPK - są one uważane za dzieci z prawego łoża, gdyż pochodzą z mniemanego małżeństwa ${ }^{47}$.

\section{Zakończenie}

Zarówno obowiązujące w Polsce prawo świeckie, jak i obowiązująca kodyfikacja kanoniczna w małżeństwie upatrują wyłączną wspólnotę dwojga ludzi skierowaną ku założeniu rodziny. Wśród istotnych przymiotów małżeństwa panuje konsens, że zawiązany w momencie zawierania związku węzeł, ustaje w momencie śmierci jednego z małżonków.

\footnotetext{
${ }^{46}$ Niestety obowiązujące prawodawstwo nie podjęło się unormowania takowego przypadku. Wydaje się słusznym więc wnioskować, aby oboje małżonkowie stawili się osobiście u odpowiedniego biskupa, najlepiej po przeprowadzeniu państwowych postępowań o tzw. przywrócenie do życia, w wyniku którego osoba uzyska dokumenty potwierdzające jej tożsamość, a tym samym prawny fakt jego życia.

${ }^{47}$ Kan. 1137 KPK: „Za dzieci prawego pochodzenia uważa się poczęte lub urodzone z małżeństwa ważnego lub mniemanego".
} 
Medycyna rozumie śmierć jako biologiczne zakończenie życia jednostki, które następuje w wyniku ustępowania czynności życiowych człowieka. Udoskonalane przez lata medyczne kryteria śmierci stanowią pomoc do określenia prawnego statusu osoby, a co za tym idzie, do oceny istnienia bądź nieistnienia jej małżeństwa ${ }^{48}$. Stwierdzenie przez lekarza śmierci, wydanie karty zgonu, a następnie przez urząd wydany akt zgonu, wywołuje automatyczne ustanie małżeństwa na obydwu forach prawnych.

Dla żyjącego współmałżonka obydwa ustroje prawne wywołują te same skutki - osobie przyznany zostaje status wdowy/wdowca otwierający furtkę do ponownego zawarcia małżeństwa.

Istnieją jednakże przypadki, gdy współmałżonek jest długotrwale nieobecny i brak z nim jakiegokolwiek kontaktu, a druga strona, chcąc uregulować swój status prawny, występuje do sądu o stwierdzenie domniemanej śmierci współmałżonka. Może ona to uczynić na obydwu płaszczyznach prawnych. W obydwu procesach ważnym czynnikiem jest długotrwała nieobecność osoby, która uważana jest za zaginioną, z którą nie ma kontaktu, a która nie miała nigdy zamiaru upozorowania swojego zaginięcia, celem zmiany dotychczasowego życia. W określeniu tej kwestii ważną rolę odgrywają zeznania wiarygodnych świadków, analiza dokumentów dotyczących zaginionej osoby, a także pogłoski i przypuszczenia dotyczącego jej zniknięcia.

Wydane przez sąd cywilny i/lub przez ordynariusza diecezji stwierdzenie domniemanej śmierci ma jedynie charakter deklaracyjny. Dokument potwierdza, że wysoce prawdopodobną przyczyną nieobecności zaginionego może być jego śmierć.

Chociaż przebieg procesu i jego sentencja wydają się być na obydwu forach prawnych takie same, to przy pogłębionej analizie można zauważyć znaczące rozbieżności dotyczące statusu małżeństwa wdowy/wdowca w optyce ewentualnego cofnięcia skutków wydanej

\footnotetext{
${ }^{48}$ Chodzi mianowicie o skrajne przypadki osób, które w wyniku urazu mechanicznego głowy lub poważnej choroby, przestają wykazywać jakiekolwiek funkcje mózgowe, a pozostałe funkcje życiowe człowieka podtrzymywane są przez aparaturę zewnętrzną.
} 
deklaracji. Prawodawstwo państwowe przewiduje, że w przypadku odnalezienia się zaginionego jego małżeństwo nie może zostać konwalidowane, gdyż prawo nie przewiduje takiej przyczyny. Nawet gdyby współmałżonek, po ogłoszeniu jego domniemanej śmierci, nie wszedł w nowy związek małżeński i chciał powrócić do wspólnoty z odnalezionym, prawo umożliwia im to jedynie na drodze powtórnego małżeństwa. W przypadku kodyfikacji kościelnej, po odnalezieniu się osoby domniemanie martwej, jego dawne małżeństwo zostaje uważnione i przywrócone do stanu faktycznego. Małżeństwo jest jedno, trwałe i nierozerwalne, a więc odzyskuje swoją moc nawet, gdyby wdowa/wdowiec, po uzyskaniu deklaracji od biskupa, zawarł(a) nowy związek małżeński. W takim przypadku stwierdza się, że to powtórne małżeństwo nigdy nie zostało ważnie zawarte, chociaż zawierane było $\mathrm{w}$ dobrej wierze $\mathrm{z}$ racji na przypuszczalne domniemanie śmierci.

\section{Death as a cause element of dissolution of the marriage bond}

State legal regulation in Poland as well as Canon Law perceive in marriage an exclusive partnership of man and woman ordered toward starting a family. Among the essential properties of marriage prevails a consensus that it cannot be dissolved for any reason other than death.

Medical death criteria, improved through years, constitute help to determine legal status of a person and, thus, to assess existence or non-existence of marriage bond. Medical death diagnosis and then issuing death certificate by proper state office, brings about an instant dissolution of a marriage in both legal systems and, thus, grants the other person widower status which in turn allows him/her entering another marriage.

There are some cases, however, when the spouse is long-term absent and there's no contact with him/her and the other spouse willing to settle his/her legal status appeals to the court to declare presumed death of the missing spouse. She/he can do so in both legal systems. The deciding factor is long-term absence of the spouse combined with lack of contact.

Confirmation of presumed death issued by court and/or local ordinary is declaratory in nature. It confirms that death could be highly probable reason of missing the person. 
Though the course of the trial and its sentence seem to be equal in both legal systems, yet through thorough analysis it may be noted that there are significant discrepancies regarding legal status of a widower as far as possible revoking the legal consequences of the confirmation issued is concerned. State legislation stipulates that in case of finding the missing spouse, his/ her marriage cannot be con-validated, because the law does not envisage such a possibility. Even if the spouse, following the declaration of presumed death, had not entered another marriage and would want to reunite with the found spouse, the law enables them to do so only in the way of another marriage. In case of Canon Law, following recovery of the presumably death spouse, his/her marriage is legally validated. Marriage bond is unique and durable, and it regains its power even if the widower, after obtaining the declaration of presumed death of his/her spouse from the local ordinary, entered another marriage. In that case is states that the new marriage had not been validly ratified, even though it was entered in good faith (presumed death of the spouse).

SŁOWA KLUCzowE: małżeństwo; nierozerwalność; domniemanie śmierci; ustanie małżeństwa; konwalidacja

KEYWORDS: marriage; indissolubility; presumed death; dissolution of a marriage; convalidation

\section{Nota o Autorze:}

Ks. DR hab. KaZimierz Dullak, Prof. US - Dziekan Wydziału Teologicznego Uniwersytetu Szczecińskiego, kierownik Katedry Prawa Kanonicznego. 